\begin{tabular}{l} 
RCCS \\
\hline Annual Review
\end{tabular}

\section{RCCS Annual Review}

A selection from the Portuguese journal Revista Crítica de Ciências Sociais

5 | 2013

Issue no. 5

\title{
Biolegality, the Forensic Imaginary and Criminal Investigation
}

\section{Helena Machado and Susana Costa}

Translator. Sheena Caldwell

\section{OpenEdition}

\section{Journals}

Electronic version

URL: http://journals.openedition.org/rccsar/490

DOI: $10.4000 /$ rccsar.490

ISSN: $1647-3175$

Publisher

Centro de Estudos Sociais da Universidade de Coimbra

Electronic reference

Helena Machado and Susana Costa, « Biolegality, the Forensic Imaginary and Criminal Investigation », RCCS Annual Review [Online], 5 | 2013, Online since 01 October 2013, connection on 01 May 2019.

URL : http://journals.openedition.org/rccsar/490 ; DOI : 10.4000/rccsar.490 


\section{Helena Machado}

University of Minho, Portugal

\section{Susana Costa}

Center for Social Studies, University of Coimbra, Portugal

\section{Biolegality, the Forensic Imaginary and Criminal Investigation ${ }^{*}$}

This text discusses some aspects of the local configurations of social representations and uses of DNA technology in criminal investigations in Portugal. The approach to the sociotechnical network which aligns forensic science with state governance policies, criminal investigation practices and laws, and the cultural imaginaries surrounding DNA and criminal investigation work is based on the concepts of biolegality and the forensic imaginary, which are, in turn, anchored in notions of biocitizenship and bioidentification, respectively. An interpretative and qualitative theoretical-methodological perspective has been adopted, based on an analysis of legislation and an understanding of the meanings and relevance attributed to the use of DNA technology by members of the Portuguese Criminal Police. The objective is to discuss aspects of the local tensions created by processes involving the export of DNA technology, which has its origins in societies and cultures with different traditions of technology governance, regulation of criminal investigation procedures and submission of evidence in court.

Keywords: database; biolegality; forensic imaginary; criminal investigation; DNA technology.

\section{Introduction}

Police criminal investigation work and the creation and expansion of genetic databases for forensic purposes are based on a sociotechnical network which aligns forensic science with state governance policies, laws and criminal investigation practices, fuelling cultural imaginaries that combine a belief in the infallibility of the use of DNA technology to identify criminals with the promise of effectively fighting crime. It involves the coproduction of criminal justice and technoscience - an "idiom" (Jasanoff, 2004) - that produces "centres of calculation" (Latour, 1987) that have effects on both the practices of actors working within the justice system - the courts, police and forensic experts - and the governmentality of the bodies and identities of those subjected to the collection, classification, storage and management of information (Machado et al., 2010).

\footnotetext{
* Article published in RCCS 97 (June 2012).

Based on research supported by the Foundation for Science and Technology (Ministry of Science, Technology and Higher Education) and developed at the Center for Social Studies, University of Coimbra, as part of the following projects: "Forensic DNA databasing in Portugal - contemporary issues in ethics, practices and policy" (FCOMP-01-0124-FEDER-009231), coordinated by Helena Machado; and "DNA and criminal investigation - a comparative sociological analysis of development and impact in Portugal and the United Kingdom," coordinated by Susana Costa (SFRH/BPD/63806/2009).
} 
In this text we discuss certain local outlines and configurations created by the use of DNA technology in criminal investigation work in Portugal. Our approach is based on an analysis of the law that created and regulates the operations of a DNA database for forensic purposes and of the law that establishes the principles for the organisation of criminal investigation work, as well as on an interpretation of the meanings attributed by officers of the Polícia Judiciária (Criminal Investigation Police) to the use of DNA technology in criminal investigation practices in Portugal. In the first section we present a summary of the theoretical debate on the relationship between criminal justice and biotechnology, on the basis of concepts of biolegality and the "forensic imaginary," which are, in turn, based on the ideas of biocitizenship and bioidentification, respectively. In the second section we discuss certain local outlines and configurations created by the use of DNA technology in criminal investigation work in Portugal. Based on an analysis of legislation and interviews held with members of the Criminal Investigation Police, ${ }^{1}$ we analyse some of the local tensions created by the export of DNA technology to societies and cultures with different histories of technology governance, regulation of criminal investigation practices and submission of evidence in court. We also argue that the contingencies associated with the use of DNA technology in criminal investigation work in Portugal can have an impact on public confidence in the criminal justice system.

\section{Biolegality and the forensic imaginary}

The concept of biolegality, a term proposed by Lynch and McNally (2009) to refer to the coproduction of biotechnology and legislation within the context of criminal justice, entails two main elements: on the one hand it refers to interactions between law and science, resulting in attempts to make genetics conform to the needs and constraints of the judicial legal system; on the other hand, it broadens the debate on forms of biocitizenship by extending the discussion on new configurations of identity and citizenship to the application of genetics in criminal investigation work - in other words, to suspect identities associated

\footnotetext{
${ }^{1}$ The interviews result from ongoing research conducted by Susana Costa, involving actors from the different national criminal police bodies. The interviewees were selected on the basis of one fundamental criterion: all potential participants had to have had previous professional experience that provided them with specialist knowledge of the field of criminal investigation in Portugal. This article focuses on a group of six interviews held in 2011 with members of the Criminal Investigation Police.
} 
with individuals or groups identified as having a high risk of committing crime, who should be watched and investigated.

The theoretical debate on biocitizenship has centred on emerging forms of citizenship anchored in concepts of health and biology (Rose, 2007), and one of the most widely discussed topics concerns the transformation of bodies and identities through technological applications and medical knowledge. The application of new genetic technologies constructs new individual and collective identities - "techno-scientific identities" (Rabinow, 2008) which are "generating new 'biosocialities' - new modes of social relationships deeply linked to living with such identities" (Clarke et al., 2009: 23). Recent literature on the new identities and new forms of citizenship resulting from the application of genetic technologies has focused mainly on medical identities associated with healthy and sick individuals/groups at risk and on civic identities based on social movements which defend the rights of patients and families facing problems of a medical and genetic nature (Akrich et al., 2008; Atkinson et al., 2007; Gibbon \& Novas, 2008).

Biolegality extends the theoretical debate and the empirical application of the idea of biocitizenship to the context of government policies designed to fight and deter crime by strict surveillance of suspect bodies - or what may be called "genetic suspects" (Hindmarsch and Prainsack, 2010). In this sense, and in the words of Lynch and McNally, "instead of producing 'at risk' medical identities, biolegality produces 'risky' suspects, 'pre-suspects' and 'statistical suspects'" (Lynch and McNally, 2009: 284). Suspect identities therefore emerge from both criminal investigation practices and genetic expertise in the development and use of DNA databases for forensic purposes. Yet they are also constructed by the subjects themselves who are the targets for the collection of biological samples and whose profiles are included in increasingly complex technological systems for computerising and systematising genetic information which may be cross-referenced with other types of information of interest to the police (their biography or 'criminal career', criminal records, fingerprints, photographs, etc.) (Prainsack and Kitzberger, 2009; Machado et al., 2011a).

Identification created by the DNA profile produces the illusion of certainty, the removal of doubt and the perception of the infallibility of technology, minimising any ambiguities and practically eliminating the possibility of doubt and uncertainty (Aas, 2006: 150), the key elements which fuel the so-called "forensic imaginary" associated with the construction of DNA profile databases. 
According to Williams (2010), this forensic imaginary combines two central ideas, namely that biology and genetics are sciences that can efficiently identify individuals, thus making them central to crime scene analysis - i.e. bioidentification - and that the growing use of DNA profiles will improve the efficiency of criminal investigation and thus prevent and deter crime.

Various authors have discussed the role of bioidentification - or identification via the body, including identification from DNA profiles but also dactyloscopy (identification from fingerprints) and anthropometry (identification using physical measurements of the human body) used in various countries throughout the world including Portugal in the $19^{\text {th }}$ century (Cole, 2002) - as an integral feature of the development of the modern state apparatus (Cole \& Lynch, 2006; Garland, 2001; Lyon, 2001). In this way, the criminal's career becomes visible to the state and potentially dangerous bodies are more easily controlled: a link is created between a particular (unique, identified and individualised) body and a state archive (databases of criminal records, fingerprints and, more recently, DNA profiles). This is a "credible link" for scientists, bureaucrats and judicial actors, as well as the general public (Cole, 2002), and is connected with political and social processes that legitimise the scientifization of police work in conjunction with the creation and expansion of databases containing genetic information for the purposes of criminal investigation.

The forensic imaginary therefore represents what some authors have called the imaginary of the "truth machine" (Lynch et al., 2008), which, to a great extent, is fed by the cultural messages transmitted by the media. There is a vast amount of literature nowadays on the so-called CSI effect, a reference to the famous television series Crime Scene Investigation, whose structure and narrative logic appear to promote public perceptions of forensic science, particularly DNA technology, as a kind of "super science" which is absolutely infallible in combating crime. The CSI effect was originally used to assess allegedly distorted perceptions of forensic science by jurors in real-life trials, which would supposedly translate into an emphasis on the assessment and valuation of DNA evidence (for a summary of the debate, see Cole and Dioso-Villa, 2007).

Due to its "credible" mixture of elements that are both fictional and based on real-life forensic science procedures in criminal investigation work supported by advanced technologies (Deutsch \& Cavender, 2008; Durnal, 2010), CSI constitutes a cultural performance that creates myths around "wishful-thinking science" (Kruse, 2010: 88). It is 
therefore likely that, on the basis of these narratives, the public may construct an imaginary of forensic science, identification technologies using DNA profiles and the investigators themselves, which, although based on the apparent authenticity of certain techniques, ignores the contingencies of their application in the real world of criminal investigation and laboratory analysis.

This text analyses certain configurations of the tensions between biolegality and the forensic imaginary created by the legal and regulatory circumstances of criminal investigation and the biopolitical process of creating a database of DNA profiles for forensic purposes. The discrepancies between the collective imaginaries concerning the efficiency of DNA technology in identifying criminals and the local realities of the legislation which regulates both the operations of the DNA database used for criminal investigation and the organisational structure of crime investigation, judicial cultures and police practices in this area clearly illustrate the tensions created by the process of exporting DNA technology to societies and cultures that have very different histories of technology governance and ways of building public trust from the societies and cultures in which they originated. It should be emphasised that the use of DNA technology in the criminal justice system has its origins in England and the USA, both countries that have adversarial justice systems (Lazer, 2004). Thus the incorporation of DNA as scientific evidence in inquisitorial justice systems such as the Portuguese may create additional complexities which have not yet been fully discussed (Toom, 2010).

\section{Criminal investigation and DNA databases in Portugal}

In central countries which have served as the model for establishing DNA databases, such as the United Kingdom and the United States of America, there is a clear emphasis on the role of the scientifization and professionalization of the police through the use of genetics in criminal investigation (Cole, 2002; Nuffield Council, 2007; Williams, 2003; Williams et al., 2004). However, this is not the case in countries such as Portugal, where various factors combine to restrict and subordinate police investigation work to legislation: the work of the police in gathering biological samples from crime suspects is dependent on an order issued by a judge; the constraints established by Law 49/2008 of 27 August (Law on the Organisation of Criminal Investigation) increase the grey areas of crime scene management; and investment in human and technological resources for police work is insufficient (Costa, 
2003; Machado and Santos, 2012). We will begin with a brief analysis of the legal instruments which regulate the creation of the DNA database for civil and criminal identification purposes and the organisation of criminal investigation work.

In 2004, the legal system for medical-legal and forensic reports was established under Law 45/2004, limiting them to the Instituto Nacional de Medicina Legal (National Institute of Legal Medicine - INML) - a state institution directly supervised by the Ministry of Justice and its branches. Only in exceptional cases, when it is clearly impossible for the INML to provide the service, can they be produced by third parties contracted or recommended by the Institute (Article 2.2 of Law 45/2004). The central role of the INML in producing forensic reports was reinforced in 2008 by Law 5/2008, which created a DNA database for civil and criminal identification purposes: the body responsible for the database and all its operations was the INML (Article 16.1 of Law 5/2008).

Law 5/2008 contains a range of provisions that attribute control and decision-making powers concerning the creation of DNA databases to judges, who are responsible for ordering the collection of samples (Article 8.2 of Law 5/2008) and the inclusion of profiles (Article 18.3 of Law 5/2008). The inquisitorial tradition ${ }^{2}$ influenced the legislative choices, as is the case in other countries where judges and public prosecutors play a more important role in the creation of databases, for example, by assuming responsibility for the inclusion and removal of profiles, as in Germany, Belgium, Spain, France, Holland, Italy, Latvia and Luxembourg (Machado et al., 2011b).

In addition to the legal restrictions on the process of collecting biological samples from individuals suspected of criminal activity, police criminal investigation work in Portugal also faces restrictions regarding the procedure for communicating the results of the analysis by the body which has the custody of the database, the INML, which can convey them only to the judge who, in turn, communicates this information to the Public Prosecutor's Office or the criminal investigation bodies, if $s /$ he deems it necessary and when it has been duly requested (Article $19.1 \mathrm{a}$ ) and b) of Law 5/2008). Police access to genetic information during

\footnotetext{
${ }^{2}$ In the inquisitorial tradition, the judge plays a leading role in conducting the trial and assessing the evidence, heading the examination and deciding which evidence is admissible. The fundamental difference is that whereas the adversarial system offers scope for confronting two versions of the facts in order to resolve the case, the role of the court in the inquisitorial system is to "determine the truth" (Toom, 2010). In the conclusions to this text the main differences between the inquisitorial and adversarial systems will be discussed in detail in order to provide a perspective on the respective impacts of the two different systems in terms of the admission and assessment of evidence, specifically with regard to the submission of DNA evidence in courts.
} 
the course of criminal investigations is therefore very restricted, hierarchical and bureaucratic.

These restrictions on police work are also heightened by the hierarchical organisation of criminal investigation work, regulated by Law 49/2008 of 27 August, which, although directed by the judicial authority (Article 2.1 of Law 49/2008), is also assisted by the criminal police bodies: the Polícia Judiciária (PJ - Criminal Investigation Police), ${ }^{3}$ Polícia de Segurança Pública (PSP - Public Security Police) and the Guarda Nacional Republicana (GNR - National Republican Guard) ${ }^{4}$ (Article 2.2 and 2.3 of Law 49/2008), with the PJ being supported in its investigations by the Laboratory of the Criminal Investigation Police and the PSP by the Unidade de Polícia Técnica (UPT - Technical Police Unit).

The forensic imaginary of the infallibility and efficiency of DNA technology is based on judicial and criminal investigation practices and cultures in countries which not only have significantly expanded the genetic databases used to investigate and combat crime (due to an almost total absence of restrictions on the inclusion and retention of profiles), but have also conferred broad powers on the police with regard to the process of collecting and analysing samples and obtaining access to information. For example, whereas in Portugal biological samples can only be collected from formal suspects and those convicted of premeditated crimes involving an effective prison sentence of 3 years or more, following an order issued by a judge (Article 8 of Law 5/2008), in England and Wales the police may collect biological samples from anyone under arrest and the profiles are retained indefinitely.

As previously stated, the differences concerning the countries that have provided the model for investing in and developing the applications of DNA technology within criminal investigation work create local tensions that may even reinforce images of the inefficiency of the Portuguese police (Machado and Santos, 2009a; Machado and Santos, 2009b). This can be seen by comparing the police investigation procedures and the ways of accessing and using genetic information in crime investigations that can be found today in Portugal involving a genetic database that is still in its early stages, with many restrictions on its

\footnotetext{
${ }^{3}$ The PJ is supervised by the Ministry of Justice (MJ).

${ }^{4}$ The Polícia de Segurança Pública (PSP) has the primary function of safeguarding internal security and protecting the rights of citizens. The Guarda Nacional Republicana (GNR) is militar in nature but is primarily involved in neighbourhood police work, intervening in areas such as domestic violence and the protection of nature and the environment. Both PSP and GNR are supervised by the Home Office (MAI).
} 
expansion and very limited police access - and the situation in England, for example - the country which has the oldest DNA database in the world (created in 1995) and which has pioneered the uses of DNA technology in criminal investigation work.

\section{The scientifization of police work and local contingencies}

The legitimation of police criminal investigation work has resulted, to a large extent, from what may be termed the scientifization of police work, supported by the growing use of technology in procedures to secure the crime scene and collect and analyse traces, combined with one of the foundation stones of the "forensic imaginary," namely the need to use advanced technologies to increase the speed and efficiency of criminal investigation work (Lynch et al., 2008; Williams and Johnson, 2008).

A substantial part of the technologies that support this police work is based on the development and expansion of modern systems for human identification and classification of individuals on the basis of biological characteristics, such as fingerprints and DNA databases. As Caplan and Torpey state, the history of criminal investigation has been defined by "repeated efforts to rationalize and standardize practices of identification and the systems for the storage and retrieval of the expanding documentation that this generated" (Caplan and Torpey, 2001: 9).

Within the range of technological resources applied to criminal investigation, the collection of traces from crime scenes and of biological samples from suspects and formal suspects stand out nowadays. These can be compared with the existing biological material or genetic profiles in police archives or forensic databases, and the use of the latter is increasing significantly throughout the world (Hindmarsh and Prainsack, 2010). Police criminal investigation work supported by DNA technology is an illustration of the way in which technology can act as a centripetal force that gathers, organises and holds together a wide range of social, political, technological, human and non-human elements (Latour, 1987), creating what Michel Callon has termed an actor network to describe a set of heterogeneous elements linked by a technological network which "could at any moment redefine their identity and mutual relationships in some new way and bring new elements into the network" (Callon, 1987: 93).

Applying this idea to the uses of DNA technology in criminal investigation work, it may be established that the human social actors consist of the crime investigators, forensic experts, 
perpetrators of crimes and the courts, whilst the non-human set of actors includes DNA identification technology and other technologies used in criminology such as lophoscopy, dactyloscopy or ballistics. Non-human social actors may also include the entire range of items and traces left at the crime scene, ${ }^{5}$ the so-called "silent witnesses" or "dumb witnesses" to the criminal act, of which the perpetrator may have inadvertently left a potentially incriminating trail (footprints, fingerprints, fibres of fabric, hair, blood, semen, etc.).

Within this context, in the following sections we will analyse representations of the role of DNA technology and the constraints on police work that result, according to the actors interviewed, from the disparity between the tensions created by the forensic imaginary the idea, widely disseminated both by the media and by the political powers and some fringes of the forensic expert community, that the growing use of DNA profiles will improve the efficiency of criminal investigation - and the constraints created locally, both in the field (in crime scene management) and through legislation.

\section{Crime scene management and DNA database assessment}

The site where a crime takes place requires the intervention of criminal police investigation bodies (OPCs) to recover any traces left there. As a rule, crimes of a sexual nature and homicides demand the most exacting type of work in which the use of DNA technology may be more necessary, although this does not invalidate the use of other techniques to gather traces, such as fingerprinting.

Portuguese law establishes that the first step to be taken by the police after a crime is reported is to inform the Public Prosecutor's Office (Article 248 of the Code of Criminal Procedure - cf. Castelo \& Pereira, 2007). ${ }^{6}$ However, even before receiving orders from the

\footnotetext{
${ }^{5}$ Criminalistics, a science whose aim is to identify extrinsic objects relating to crimes and criminal identification, is traditionally described as the "science of individualization" (Kirk, 1963). Forensic science makes a distinction between identification and individualization. Whereas individualization signifies the possibility of defining a unique source as the origin of a trace taken from a crime scene from a range of other possible sources, identification only narrows down the potential source of origin to a group or class of objects (Cole and DiosoVilla, 2009: 3), to the extent that "it is the process of establishing the identity of an individual, this being a group of features which individualize him" (Pinheiro, 2008: 13). A new epistemology of forensic identification (Cole, 2009) now claims that it is impossible to achieve "perfect" individualization, and so one should speak in terms of probabilities rather than certainties (Saks and Koehler, 2005). In the case of forensic genetics, DNA only allows for identification and not individualization (Amorim, 2012).

${ }^{6}$ It is the responsibility of criminal police bodies, even on their own initiative, to gather information about crimes and as far as possible prevent their consequences, discover the perpetrators and execute the necessary and urgent measures required to safeguard evidence.
} 
appropriate judicial authority, OPCs may proceed with the necessary and urgent measures required to secure evidence, and continue after the intervention of the Public Prosecutor's Office to recover new evidence (Article 249.1 \& 3, respectively - cf. Castelo \& Pereira, 2007).

As set out in Article 7 of Law 49/2008, crimes involving homicide and sexual aggression are, in particular, the responsibility of the Polícia Judiciária, assisted by the Laboratory of the Criminal Investigation Police. The technical police unit working with the PSP or the GNR is, in turn, responsible for carrying out the necessary investigations with a view to producing material evidence of a crime, such as an inspection of the area, preservation of any traces found, preservation of the crime scene, securing the area and denying access to outsiders, searches, the questioning of witnesses in order to determine what took place and, in certain circumstances, the collection and removal of traces, together with an identification of the crime scene, either in the form of a written description or with the additional use of audio and video equipment to assist in the process. Thus, given the nature of its responsibilities and the human, material, technical and scientific instruments at its disposal, the Laboratory of the Criminal Investigation Police assumes a rearguard position, stepping in after another criminal investigation body has carried out the initial investigations (Article 3.4 a) and b) of Law 49/2008).

However, what the law establishes is based on the assumption that all OPCs are capable of intervening swiftly and efficiently at the crime scene, not only complying with the principle of the immediacy and urgency of the actions (Braz, 2010: 36), but also the principle that the first police body to be informed of the crime should be the one to proceed to the scene and carry out the initial investigations, with a view to preserving the crime scene and executing the initial protective measures which are so important to the future investigation.

The initial phase, known as the judicial inspection, implies careful analysis of the crime scene in order to gather physical and witness evidence. It is a crucial stage and, above all, important to the strategic planning of subsequent interventions and to determining who is responsible for the management of the crime scene. In fact, the existence of a "golden hour" ${ }^{\prime 7}$ associated with the crime scene is reflected in all the subsequent phases of the criminal investigation. Originating in work developed by English police bodies, as some of our interviewees reported, it is based on the idea that the first hours of investigation following a crime are crucial to discovering the truth or finding the key to the enigma.

\footnotetext{
${ }^{7}$ This English expression was used several times by the interviewees.
} 
Consequently, in a specific crime scenario, the faster the police intervene, the greater the chances are of police officers providing an accurate description of what they have found there, making it necessary to intervene as quickly as possible and preserve as much of the scene as possible, keeping it close to the original scene at the time when the crime took place.

The period of judicial inspection which precedes the more technical and specialised criminal investigation work may therefore be considered a crucial phase for solving the "puzzle." However, it is perhaps the most vulnerable phase in the entire process, since a crime scene is also a "complex, precarious and fragile" site (Braz, 2010: 212) that can easily be destroyed and may be damaged by external factors (weather conditions), human factors (contamination), incorrect procedures, and a lack of appropriate human and material resources, among other elements.

According to the interviewees, the discrepancies between the different OPCs, whether in terms of human resources or their level of specialisation and training, are well known, and different kinds of knowledge and practices amongst the police forces intervening in crime scenes are also evident. As one interviewee stated, weakness in the training of members of other police forces may compromise the success of criminal investigation work:

Some members of other police forces are not very aware of what has to be done. So, until the Polícia Judiciária arrive on the scene what happens is that the other police have to preserve the area. They do it much better and more thoroughly now than they used to a few years ago! There's no comparison! But even so, maybe because they've been poorly trained [...] despite good intentions, it's not done properly [...]. And this is one of the difficulties we face.

As previously stated, the police officers who arrive first at the crime scene - usually the GNR or PSP - are responsible for carrying out the initial investigations, later assisted by the specialist police forces. ${ }^{8}$ On the basis of the information which these first actors communicate to the other entities, the crime can be classified, and according to this classification, the following can be decided: Who is responsible for managing the crime scene? Who coordinates the operations? Who directs them? Who authorises the actions to be taken? What type of intervention and technical instruments are required? Which operational agents should be dispatched to the scene? Who carries out the work?

\footnotetext{
${ }^{8}$ As stated in Article 171.4 of the Code of Criminal Procedure, "If the judicial authority or appropriate criminal police body is not present at the scene, it is the responsibility of any law enforcement officer to provisionally carry out the measures referred to in Point 2 if the obtaining of evidence is otherwise threatened" (cf. Castelo \& Pereira, 2007).
} 
According to one of the interviewees, the ambiguities in the law and the difficulties in producing a correct classification of the crime in the field, which would enable decisions to be made on responsibilities for managing the investigation, create difficulties in operationalizing police work and, in his words, "we can still see that a lot of things are made impossible because of bad management of the [crime] scene." The same interviewee added that it is sometimes difficult to define who is responsible for collecting samples in a given context: "[W] hen a crime occurs at a certain location, anything that has to do with a place, with an event, the first problem to sort out is knowing which police body is responsible for dealing with it." He went on to emphasise the conflicts ${ }^{9}$ which these grey areas create in terms of fieldwork: ${ }^{10}$

Sometimes there are battles over responsibilities [...] and sometimes the reason why things happen and the perception of why [the police forces] failed in the field [...] is not fully explored. For example, the question of stolen vehicles: without question, this is the responsibility of the GNR, but very often the vehicle becomes the responsibility of the PJ [...] when it's a matter of vehicle trafficking and falsification. [...] The crimes that take place [that are the responsibility of the PJ] don't always come clearly labelled... ${ }^{11}$

One factor that may create additional contingencies for criminal investigation concerns precisely the fact that initially it is not always possible to identify the type of crime in question.

The same interviewee also adds that, in his opinion, the "other police" do not have the specialist technical training or material resources to package the material gathered from crime scenes or, even if they do, they frequently misuse this material.

[...] nowadays the rule for correct packaging stipulates a set of sample bags for each of the items depending on type and size, following two principles [...]: first, anything organic is put in [...] a paper bag and anything volatile in a hermetically sealed bag. In practice, we sometimes get exactly the opposite!

\footnotetext{
${ }^{9}$ Article 9 of Law $49 / 2008$ states that "if two or more criminal police bodies consider that they are not qualified for investigating the same crime, the conflict shall be decided by the appropriate judicial authority at each stage of the process."

${ }^{10}$ Article 2.4 of Law 49/2008 stipulates that "the criminal police bodies work on the case under, and are functionally dependent on, the appropriate judicial authority, without prejudice of the judicial organisation in question." However, Article 8.1 states that the Public Prosecutor may allocate "the investigation of a crime [...] to another criminal police body provided that it is, in concrete terms, more suited to carrying out the work and specifically when: [...] d) The investigation does not require particular mobility or highly specialised technical resources."

${ }^{11}$ Article 7 of Law 49/2008 on the competences of the Polícia Judiciária in criminal investigation lists the crimes that are their responsibility.
} 
Another important issue related to the stance to be adopted by the "other" OPCs involved in the judicial investigation should also be emphasised. Their involvement in the scene may be more dynamic or more static, depending on the judgement of those actually present in the field to make this decision. A dynamic attitude on the part of the OPCs who assist in crime investigations presupposes that they limit themselves to the protective measures that are strictly necessary to preserve the original crime scene, and this is also valid for the members of the Polícia Judiciária who arrive at the crime scene whilst awaiting officers with more specific technical skills. However, the simple fact that they have to carry out the initial measures stipulated by law may, in itself, given the constraints in terms of training and the technical and human resources available, lead to poorly executed procedures. One of the ways of minimising potential errors is therefore to adopt a static position:

The first thing to do at the crime scene [is] to put your hands in your pockets! Because we all have a tendency to touch things, to see, and so the first response [is to] use your eyes and look, make this the first step, understand what is going on [...].

Therefore, according to the interviewee, if a static attitude presupposes immediately safeguarding traces to prevent any risk of any important traces - usually the preserve of the "other" criminal police forces (the GNR or PSP) - becoming damaged or spoiled, the truth is that this may mean that those that should have been collected immediately may be lost. Thus, officers with little training who opt for a dynamic attitude will fulfil their duty of safeguarding the crime scene and the traces left there. However, since this is carried out by officers who, in general, have neither the appropriate qualifications to do the work properly nor the necessary resources to ensure proper collection, it may irremediably ruin the evidence left by criminals.

When these local officers arrive at the crime scene, aware that they are not empowered to act and that they should wait for qualified personnel and resources, they may be contributing towards ensuring that important traces are damaged by third parties by not being collected in good time, i.e. within the "golden hour" that applies to all crime scenes. As one of the interviewees stated, the importance of acting in good time does not only concern the need for traces to be collected as quickly as possible to prevent any subsequent contamination, but also ensuring that all the important traces are collected at the time, 
avoiding the need to return to the scene to collect new samples which will probably not be in the same condition as the others.

[...] the English call this the "golden hour," the need to get to work as soon as the crime is reported, not only to collect traces but to get the perpetrator, because he could be escaping, etc., etc., and so we work ... when a crime is reported ... at 300 - not 200 - at 300 or 400 an hour! In these circumstances, naturally, mistakes can be made because something or other gets forgotten. Then, naturally, it's up to the team management to take responsibility, right?

Whether one or another of these attitudes is adopted, there is, in fact, always a risk. Consequently, one way of minimising this is to make a detailed record of all the steps taken by individuals approaching the crime scene, i.e. "noting entrances and exits in the assessment of the crime scene [...], because we [police/technicians] also leave footprints when we enter." This situation becomes one of the contingencies of the crime scene which is practically impossible to avoid unless, as one of the interviewees stated, the agent acts like "a dummy with a fishing rod," conveying the idea that only being suspended above the crime scene would minimise the possibility of technical staff contaminating the area, namely by leaving footprints.

[...] there are no fishing rods but he [the police officer] ${ }^{12}$ has to arrive and cause as little damage as possible to the scene he has to observe. But if he needs to go somewhere where he has to lean on a door to get in or open up a room, he has to record this afterwards! He has to say that the position of that door changed because of my entry, not because the offender escaped or any other individual came in.

Another obstacle to successful criminal investigation work concerns the restrictive nature of the legislation that regulates the creation and operations of the DNA database in Portugal. As one of the interviewees said, the law was, above all, a political solution for avoiding conflicts between different interests (forensic experts, the police and human rights activists), indicating that one of its major weaknesses is the fact that the inclusion of profiles is dependent on a decision made by a judge:

I hear complaints from all sides. [...] In the end, it's a bad law [...] you can't leave it up to a judge to decide whether a profile should be included or not, you can't! It should be automatic [...] it's the judgement of Solomon, to avoid any friction.

\footnotetext{
${ }^{12}$ In referring to the police, this interviewee includes any of the forces that deal with the crime scene, whether the PJ, GNR, PSP or even technical staff from the Laboratory of the Criminal Investigation Police (LPC) and the Technical Police Unit (UPT) of the PSP. It may be said that this is a rule which everyone should follow as closely as possible.
} 
Another interviewee referred to the limitations created by the restrictive nature of the DNA database, namely the fact that it is obligatory to eliminate profiles at the end of the case or the maximum limitation period for criminal proceedings stipulated in the Code of Criminal Procedure:

I think that there is this excessive guaranteeism regarding certain issues that are perhaps out of place. Such as the question of retaining profiles [...] criminal records have a very short lifespan nowadays! If we had rules like this for fingerprint [databases], our database would be practically useless!

The need for an efficient DNA database is also stressed in the following extract, in which the interviewee argues that DNA profiles should not be removed from the database and criticises the need for the intervention of a judge for data to be communicated to criminal investigation bodies:

The profiles should be retained indefinitely [in the DNA database]. But the law reflects a political will, and I do think it's a miracle that we finally have a law [on the DNA database]. But the efficiency of the database is going to be greatly reduced by Article $9^{13}[\ldots]$. The red tape will be endless.

The interviewees strongly criticised the inefficiency of the DNA database because it made the retrospective use of information that could have been obtained by retaining profiles impossible as a basis for comparison with biological material collected from a crime scene:

A micro-database, a pseudo-database which, in essence, won't tell me anything more than the fact that the individuals who are in it were criminals [...] What I really want is a database constructed in such a way that it can tell you who someone is from a biological trace found at the crime scene.

These discourses clearly illustrate the tensions created by legislation which, on the one hand, is framed by a legal culture that subordinates the role of the police to judicial authority but, on the other hand, reversed the logic behind the functioning of the DNA database, favouring the power of forensic science. As one of our interviewees stated,

The use of DNA in criminal investigation work has been subordinated to the interests of scientific research. Without denying the merits of research, I would say that it is an unduly lengthy process that is directed more towards scientific discovery. This rationale does not serve the interests of the police and criminal investigation: we have to have responses in good time.

\footnotetext{
${ }^{13}$ Article 19.1 of Law 5/2008, mentioned by the interviewee, establishes the following: $a$ ) Data is sent from the INML to the appropriate judge according to the type or stage in the proceedings, and following a duly justified request; $b$ ) The judge referred to in the previous point communicates the said data, when considered necessary or upon duly justified request, to the Public Prosecutor's Office or criminal police bodies, providing a decision by reasoned order.
} 
One of the fundamental premises for the success of a DNA database for purposes of criminal investigation is the possibility of increasing the amount of information gathered by extending the criteria for the inclusion of profiles and their non-removal (McCartney, 2006: 55-57). The genetic suspect referred to earlier derives from the retrospective use of genetic information, and features as a pillar of biolegality and the forensic imaginary. In the light of these interviews, it may be said that the main elements in the political message of the efficiency and infallibility of DNA technology in identifying criminals and combating and deterring crime would appear to be compromised.

\section{Conclusion}

The models for criminal investigation police work and the use of DNA technology to identify individuals that prevail in the collective imaginary - both in government discourse and in the cultural messages conveyed by the media - reproduce, with a greater or lesser degree of truth, criminal investigation practices in countries such as England or the USA that are based on the following: (1) the existence of very extensive DNA databases and broad police powers with regard to the collection and analysis of genetic information; (2) material and scientific resources which provide materials and technical guidelines for the collection of material from crime scenes in accordance with scientific procedures that do not compromise the chain of custody; (3) organisational cultures that clearly establish the principles, routines and practical actions relating to criminal investigation procedures, through which the materials destined for laboratory work and the results of scientific analysis subjected to peer scrutiny and auditing are produced (Williams and Johnson, 2008: 6-7).

The interviews reveal the position of the Polícia Judiciária within the sociotechnical network created by the uses of DNA technology in criminal investigation. The results show how this network involves heterogeneous elements, social actors who occupy different positions in social relationships involving power and the legitimation of expert knowledge. Actors invested with different capacities to use genetic information in criminal investigation are confronted, on the one hand, with the symbolic subordination of law to forensic science, which appears to characterise the regulatory culture of Portuguese society (Santos, 2002) and, on the other hand, the hierarchical and operational subordination of the police to the judicial authority assisted by forensic science (Machado, 2011). 
As concluded by Costa (2003), there are tensions between laboratory work involving the analysis of materials collected from crime scenes, which seeks to harmonise with international forensic science procedures, and specific local features produced by the Portuguese legal system. At the same time, criminal investigation work supported by DNA technology appears to clearly illustrate the variety of ways of incorporating science and technology derived from specific national and local features. The contingencies associated with criminal investigation in Portugal reveal a complex interconnection of knowledge and practices, particularities of the legislation that not only regulate the organisation of police work but also the creation and use of a DNA database for criminal identification. They are indicative of an investment in the globalisation and harmonisation of procedures based on the experiences of other countries, but nevertheless grounded in a legal, professional and criminological culture with national and local features and particularities.

In short, the reality of criminal investigation work in Portugal appears far removed from the models of biolegality and the forensic imaginary projected by countries that already have wide-ranging experience of using DNA technology for three reasons: (1) the lack of technical and scientific training for the PSP and GNR and of material resources to enable these police forces to collect traces efficiently from crime scenes; (2) the ambiguity of the law and the difficulties involved in applying it practically in terms of clearly defining responsibilities for criminal investigation work; (3) legal restrictions on using and accessing information stored in the DNA database supervised by the INML, and the lack of operationality of this type of instrument to support criminal investigation work.

In addition to these factors, which explain the discrepancy between the Portuguese situation and the model of biolegality and the forensic imaginary originating in countries that have routinely used DNA technology for decades, there are also considerable differences in terms of the functioning of the courts. The incorporation of DNA technology into criminal investigation practices originated in the adversarial justice system, for example the American or English system, whereas the Portuguese system is based on an inquisitorial regime. In adversarial systems, the trial is the occasion for a confrontation between the representatives of the state and the accused, in which the presentation and discussion of the evidence is liable to be publicly deconstructed in court. This enables the soundness of the evidence to be tested or, conversely, its weaknesses, any technical doubts, or even the possibility of a breakdown in the chain of custody. Therefore the adversarial process may be characterised 
by attempts to discredit evidence submitted by the other party and by the triumph of one of the versions presented to the court and jury (Cooper, 2004). It is precisely this "regime of scepticism" aimed at deconstructing scientific evidence that can be seen in the adversarial system (Toom, 2010: 176) which enables the defence and the prosecution to confront each other, or even the discourse of the expert(s) (Jasanoff, 2006). The role of the judge in the adversarial process is that of a passive and impartial arbitrator who is responsible for defining the rules of the trial and the admissibility of the evidence that is presented. The judge does not conduct the inquiry or prescribe measures for collecting evidence, and the parties present autonomous arguments based on different versions of the facts.

In contrast, in inquisitorial legal systems, as is the case in Portugal and most countries in Western Europe, the judge plays an active role as a 'fact finder', and rulings are based on judicial inquiry and the search for the 'truth'. In countries such as Portugal, the Public Prosecutor bears the burden of proof and, even though the defence may request counterproof and additional expert opinions, these have to be accepted by the judge. These characteristics of the Portuguese justice system mean that the practice of admitting counterproof in courts is rare (Costa, 2003; Costa et al., 2003) and may have two different consequences: less use of DNA evidence in trials in Portugal (Machado and Prainsack, 2012: ch. 3), and the creation of a scenario which favours perception of this technology as a "truth machine" (Lynch et al., 2008) which is not contested due to the abovementioned restrictions on the admission and assessment of counterproof.

Finally, it should be stated that popular representations of criminal investigation and the justice system are frequently based on a comparison between real-life cases and the imaginary projected by fictional representatives of the police, in which the use of sophisticated technology, scientific methods and brilliant deductions can solve the most complicated cases speedily and without error (Machado and Santos, 2012). As we have seen, the narratives of fictional criminal investigation series, specifically the television series Crime Scene Investigation (CSI), may create a disproportionate belief in the efficiency of criminal investigation work supported by DNA identification technologies. In this sense, the creation of unrealistic expectations may lead to an increase in negative assessments of the work of the Portuguese police amongst the general public in Portugal, and thus reduce confidence in the criminal justice system (Machado and Santos, 2012). In fact, real-life criminal cases widely covered by the media in Portugal that remain unsolved - of which the case of the 
disappearance of Madeleine McCann is a prime example - may reinforce images of the inefficiency of the Portuguese police that also coincide with negative representations of the justice system in Portugal, which is seen as slow, inefficient and discriminatory.

\section{Translated by Sheena Caldwell}

Revised by the authors and Teresa Tavares

\section{References}

Aas, Katja (2006), “'The Body Does Not Lie': Identity, Risk and Trust in Technoculture," Crime, Media and Culture, 2(2): 143-158.

Akrich, Madeleine; Nunes, João; Paterson, Florence; Rabehariso, Vololona (eds.) (2008), The Dynamics of Patient Organizations in Europe. Paris: Presses de l' École des Mines.

Amorim, António (2012), "Opening the DNA Black Box: Demythologizing Forensic Genetics," New Genetics and Society, 31(3): 259-270.

Atkinson, Paul; Glasner, Peter; Greenslade, Helen (eds.) (2007), New Genetics, New Identities. London: Routledge.

Braz, José (2010), Investigação criminal. A organização, o método e a prova. Os desafios da nova criminalidade. Coimbra: Almedina $\left[2^{\text {nd }}\right.$ ed.].

Callon, Michel (1987), "Society in the Making: The Study of Technology as a Tool for Sociological Analysis," in Wiebe Bijker, Thomas P. Hugues \& Trevor Pinch (eds.), The Social Construction of Technological Systems: New Directions in the Sociology and History of Technology. London: MIT Press, 83-103.

Caplan, Jane; Torpey, John (eds.) (2001), Documenting Individual Identity: The Development of State Practices in the Modern World. Princeton: Princeton University Press.

Castelo, Tiago; Pereira, Joel (2007), Código do Processo Penal. Compilações Legislativas. Versão 1.3. Edição Verbo Jurídico. Consulted on 2 April 2013, at http://www.verbojuridico.com/download/cpp2007 v1.3.pdf.

Clarke, Adele E.; Shim, Janet; Shostak, Sara; Nelson, Alondra (2009), "Biomedicalising Genetic Health, Diseases and Identities," in Paul Atkinson, Peter Glasner \& Margaret Lock (eds.), Handbook of Genetics and Society. Mapping the New Genomic Era. London \& New York: Routledge, 21-40.

Cole, Simon (2002), Suspect Identities: A History of Fingerprinting and Criminal Identification. Harvard: Harvard University Press.

Cole, Simon (2009), "Forensics without uniqueness, conclusions without individualization: The new epistemology of forensic identification," Law, Probability and Risk, 8 (3): 233-255.

Cole, Simon; Dioso-Villa, Rachel (2007), "CSI and its Effects: Media, Juries, and the Burden of Proof," New England Law Review, 41(3): 435-470.

Cole, Simon; Dioso-Villa, Rachel (2009), "Investigating the 'CSI Effect' Effect: Media and Litigation Crisis in Criminal Law," Stanford Law Review, 61(6): 1335-1374.

Cole, Simon; Lynch, Michael (2006), "The Social and Legal Construction of Suspects," Annual Review of Law and Social Science, 2: 39-60. 
Cooper, Susan (2004), "Truth and Justice, Inquiry and Advocacy, Science and Law," Ratio Juris, 17(1): $15-26$.

Costa, Susana (2003), A justiça em laboratório. A identificação por perfis genéticos de ADN. Entre a harmonização transnacional e a apropriação local. Coimbra: Almedina.

Costa, Susana; Machado, Helena; Nunes, João Arriscado (2003), "O ADN e a justiça: A biologia forense e o direito como mediadores entre a ciência e os cidadãos," in Maria Eduarda Gonçalves (ed.), Os portugueses e a ciência. Lisbon: Dom Quixote, 199-233.

Deutsch, Sarah K.; Cavender, Gray (2008), "CSI and Forensic Realism," Journal of Criminal Justice and Popular Culture, 15(1): 34-53.

Durnal, Evan W. (2010), "Crime Scene Investigation (As Seen on TV)," Forensic Science International DOI: 10.1016/j.forsciint.2010.02.015.

Garland, David (2001), The Culture of Crime Control. Oxford: Oxford University Press.

Gibbon, Sarah; Novas, Carlos (eds.) (2008), Biosocialities, Genetics and the Social Sciences: Making Biologies and Identities. London: Routledge.

Hindmarsh, Richards; Prainsack, Barbara (eds.) (2010), Genetic Suspects: Global Governance of DNA Profiling and Databasing. Cambridge: Cambridge University Press.

Jasanoff, Sheila (ed.) (2004), States of Knowledge. The Co-Production of Science and the Social Order. London: Routledge.

Jasanoff, Sheila (2006), "Just Evidence: The Limits of Science in the Legal Process," Journal of Law, Medicine and Ethics, 34(2): 328-341.

Kirk, P.L. (1963), "The Ontogeny of Criminalistics," Journal of Criminal Law, Criminology and Police Science, 54: 235-238.

Kruse, Corinna (2010), "Producing Absolute Truth: CSI Science as Wishful Thinking," American Anthropologist, 112(1): 79-91.

Latour, Bruno (1987), Science in Action. Cambridge: Harvard University Press.

Lazer, David (ed.) (2004), The Technology of Justice: DNA and the Criminal Justice System. Cambridge, MA: MIT Press.

Lei n. 5/2008 de 12 de fevereiro, "Aprova a criação de uma base de dados de perfis de ADN para fins de identificação civil e criminal," Diário da República, 1.a série - № 30. Diário da República Eletrónico website consulted on 2 April 2013, at http://dre.pt/pdf1sdip/2008/02/03000/0096200968.pdf.

Lei n.o 49/2008 de 27 agosto, "Aprova a Lei de Organização da Investigação Criminal," Diário da República, 1.a série - N.o 165. Diário da República Eletrónico website consulted on 20 October 2012, at http://dre.pt/pdf1sdip/2008/08/16500/0603806042.pdf.

Lei n. 45/2004 de 19 de agosto, "Estabelece o regime jurídico das perícias médico-legais e forenses," Diário da República, 1. a série - № 195. Diário da República Eletrónico website consulted on 2 April 2013, at http://dre.pt/pdf1s/2004/08/195A00/53625368.pdf.

Lynch, Michael; McNally, Ruth (2009), "Forensic DNA Databases and Biolegality: The Coproduction of Law, Surveillance Technology and Suspect Bodies," in Paul Atkinson, Peter Gaslen \& Margaret Lock (eds.), The Handbook of Genetics and Society. Mapping the New Genomic Era. London \& New York: Routledge, 283-301.

Lynch, Michael; Cole, Simon A.; McNally, Ruth; Jordan, Kathleen (2008), Truth Machine. The Contentious History of DNA Fingerprinting. Chicago/London: University of Chicago Press. 
Lyon, David (2001), Surveillance Society: Monitoring Everyday Life. Buckingham: Open University Press.

Machado, Helena (2011), "Construtores da bio(in)segurança na base de dados de perfis de ADN", Etnográfica, 15(1): 153-166.

Machado, Helena; Prainsack, Barbara (2012), Tracing Technologies. Prisoners' Views in the Era of CSI. Aldershot, Hampshire: Ashgate Publishing.

Machado, Helena; Santos, Filipe (2009a), "The Disappearance of Madeleine McCann: Public Drama and Trial by Media in the Portuguese Press," Crime, Media, Culture, 5(2): 146-167.

Machado, Helena; Santos, Filipe (2009b), "Popular Press and Forensic Genetics in Portugal Expectation and Disappointment Regarding Two Cases of Missing Children," Public Understanding of Science, 20(3): 303-318.

Machado, Helena; Santos, Filipe (2012), "Entre a polícia ficcional e a polícia real: Os usos do DNA na investigação criminal em Portugal," in Susana Durão (ed.), Polícia, segurança e ordem pública. Perspetivas Portuguesas e Brasileiras. Lisbon: Imprensa de Ciências Sociais, 154-165.

Machado, Helena; Silva, Susana; Amorim, António (2010), "Políticas de identidade: perfil de DNA e a identidade genético-criminal," Análise Social, XVL(196): 537-553.

Machado, Helena; Moniz, Helena; Santos, Filipe; Silva, Susana (2011a), Análise comparativa de legislação que regula o funcionamento de bases de dados de perfis de DNA com fins forenses na Europa. Coimbra: Centro de Estudos Sociais. Consulted on 2 April 2013, at http://dnadatabase.ces.uc.pt/list documents.php.

Machado, Helena; Santos, Filipe; Silva, Susana (2011b), "Prisoners' Expectations of the National Forensic DNA Database: Surveillance and Reconfiguration of Individual Rights," Forensic Science International, 210(1-3): 139-143. DOI:10.1016/j.forsciint.2011.02.020.

McCartney, Carole (2006), Forensic Identification and Criminal Justice: Forensic Science, Justice and Risk. Cullompton: Willan Publishing.

Nuffield Council on Bioethics (2007), The Forensic Use of Bioinformation: Ethical Issues. London: Nuffield Council on Bioethics.

Pinheiro, Maria de Fátima (2008), "A perícia em genética e biologia forense - criminalística biológica," in Maria de Fátima Pinheiro (ed.), CSI Criminal. Porto: Universidade Fernando Pessoa, 11-40.

Prainsack, Barbara; Kitzberger, Martin (2009), "DNA Behind Bars: Other Ways of Knowing Forensic DNA Technologies," Social Studies of Science, 39(1): 51-79.

Rabinow, Paul (2008), "Afterword: Concept Work", in Sarah Gibbon \& Carlos Novas (eds.), Biosocialities, Genetics and the Social Sciences: Making Biologies and Identities. London: Routledge, 188-192.

Rose, Nicolas (2007), The Politics of Life Itself. Biomedicine, Power and Subjectivity in the Twenty-first Century. Princeton: Princeton University Press.

Saks, Michael; Koehler, Jonathan (2005), "The Coming Paradigm Shift in Forensic Identification Science," Science, 309(5736): 892-895.

Santos, Boaventura de Sousa (2002), Toward a New Legal Common Sense. Law, Globalization, and Emancipation. London: Butterworths.

Toom, Victor (2010), "Inquisitorial Forensic DNA Profiling in the Netherlands and the Expansion of the Forensic Genetic Body," in Richard Hindmarsh \& Barbara Prainsack (eds.), Genetic Suspects: 
Global Governance of DNA Profiling and Databasing. Cambridge: Cambridge University Press, 175196.

Williams, Robin (2003), "Residual Categories and Disciplinary Knowledge: Personal Identity in Sociological and Forensic Investigations," Symbolic Interaction, 26(4): 515-529.

Williams, Robin (2010), "DNA Databases and the Forensic Imaginary," in Richard Hindmarsh \& Barbara Prainsack (eds.), Genetic Suspects: Global Governance of DNA Profiling and Databasing. Cambridge: Cambridge University Press, 131-152.

Williams, Robin; Johnson, Paul (2008), Genetic Policing: The Use of DNA in Criminal Investigations. Cullompton: Willan Publishing.

Williams, Robin; Johnson, Paul; Martin, Paul (2004), Genetic Information and Crime Investigation. Social, Ethical and Public Policy Aspects of the Establishment, Expansion and Police Use of the National DNA Database. Durham: Durham University, School of Applied Social Sciences. 